\title{
Assessing The Impact Of Cost Inflation On Building Construction Material: A Study In Wolaita Zone, Southern Ethiopia
}

\author{
Wondimagegn Tadesse Borku', EssubalewTarkuYenialem ${ }^{2}$ \\ ${ }^{1}$ Lecturer, Department of Construction technology and management, WolaitaSodo University, WolaitaSodo, Ethiopia \\ Email id:wondetade@gmail.com \\ ${ }^{2}$ lecturer,Department of Civil Engineering, Wolaita Sodo University, WolaitaSodo, \\ Ethiopia Email id: esubalewtariku@yahoo.com \\ *Corresponding Author: Wondimagegn Tadesse Borku \\ Lecturer, Department of Construction technology and management, WolaitaSodo University, WolaitaSodo, Ethiopia \\ Email Id: wondetade@gmail.com
}

\begin{abstract}
Inflation is the process of continuously rising prices, or equivalently, of a continuously falling value of money. Price Escalation is an increase in the cost of any construction elements of the original contract and base cost of a project due to passage of time. The methods that used for this thesis were by collecting the data require for this study through preparing questionnaires.

The investigation of factors that might contribute to cost inflation on construction material is significant in order to notice attention to specific areas of improvement for building construction projects in Wolaitasodo. Accordingly, this research attempts to assess the impact of cost inflation, to identify problems of cost inflation on construction material and adjustment and methods to manage/administer cost inflation on construction material in Wolaitasodo building construction projects, which can serve as the way forward for future work in coping with this inflation. Findings revealed that the major impacts of cost inflation on construction materials which have been occurring on the projects are improper risk management and improper team organization. Quality of workman ship, risk of project abandonment and Lack of firm price quotes are the factors that cause the cost inflation on construction material and adjustment problems on Wolaita sodo building construction projects. [5] Cited [11]
\end{abstract}

Key Words: Price Escalation,Inflation Construction, Coststruction

\subsection{Background of the Study}

\section{INTRODUCTION}

Construction is defined generally as an economic activity directed to the creation, renovation, repair or extension of fixed assets in the form of buildings, land improvements of an engineering nature, and other such engineering constructions as roads, bridges, dams, etc. (international standards industrial classification)[1].

Construction industry makes significant contributions to the socio-economic development process of a country. Its importance emanates largely from the direct and indirect impact it has on all economic activities. It contributes to the national output and stimulates the growth of other sectors through a complex system of linkages. It is noted that about one-tenth of the global economy is dedicated to constructing and operating homes and offices. [4] The construction sector has significant contributions to the Ethiopian economy. The importance of the sector can be assessed by examining in detail the overall performance of the sector.

Construction industry is an important sector of any national economy, since the capital investments of any country, to the large extent, is based on efficiency of sector. Inflation became the chronic problem whose effect permeates the entire construction industry. Owners are not only paying for the increase cost of facility and capital but also for premiums on construction prices because of uncertainties of inflation and its side effects. Inflation is a persistent increase in the level of consumer prices or a persistent decline in the purchasing power of money.

\subsection{Statement of the Problem}

Asses about the impact of inflation rate on construction projects budget and find out the following conclusion that Inflation is one of the leading components that have a major impact on the economy of countries. Every industry is either positively or negatively impacted by inflation. It is noteworthy from the literature that not only does the inflation 
rate impact the industry; often industrial elements even devastate the country's inflation rate. The effect of inflation is also having on the construction industry, where many studies have highlighted the role of inflation in project cost overrun. Due to inflation the building material prices, labor wages and machinery hire rates changes every year, resulting in the project's initial budget being deviated from the final budget [3].

Most of the time projects are not completed within the planned time, budget and also sometimes within specified quality as that time cost inflation is considered as a big problem, which hinders project's progress, since it decreases the contractor's profit leading to huge losses leaving the project in a big trouble. For that it is the key importance to exert the most effort to accomplish such study, to detect the previously mention factors and to treat all the week points and from all sides and so giving specific priorities in order to avoid cost inflation at building construction projects. Therefore, the aim of the paper is to assess the problems related to cost inflation on construction material and its adjustment. [10]. Hence assessing the impact of cost of inflation from the context of wolaitasodo town building projects is important to overcome challenges face related to Construction material price inflation related problems.

\subsection{Objectives of the Study}

The central goal of this research work is to identify and determine the main impacts of inflation on construction material in Wolaitasodo building construction projects

\subsection{Definitions and Concepts}

\section{REVIEW OF LITERATURES}

Different scholars defined project price escalation in construction industry in their works and some of them are outlined as follow: Price Escalation is an increase in the cost of any construction elements of the original contract and base cost of a project due to passage of time.Price Escalation is the increase in any element of project costs when the cost of that element is compared between two different periods

Escalation is the provision in a cost estimate for increases in the cost of equipment, material, labor, etc., due to continuing price changes over time.The construction industry is generally responsible for the physical development or the transformation of the environment which makes the built environment very vital to socialeconomic development of a nation. It comprises of building, civil and heavy engineering works [2].Construction as a large sector of the economy is responsible for millions of jobs and a significant proportion of GDP in most countries. When allied to other sectors and industries in materials production and distribution as well as services sectors such as transport, finance and the property market, its impact on society and the environment and its influence on the character of the world are tremendous. Construction industry and the national economy, it becomes necessary that the cost of construction be within the reach of the average citizen. However, some economic indicators are very significant to the overall cost of construction. Some of these indicators include; exchange rate of local currency to other currencies in the world, inflation rate and interest rate charge on loan among others [6].

\subsection{Cost over runs}

Cost overrun is a common problem for both developed and developing countries in the construction industry. In construction projects, cost deviation occurs which could either be positive or negative and if it is positive, it indicates the cost overrun. There is a significant relationship between cost overrun and inflation in both public and private construction projects. According to.The major cost overrun distress is the rise in construction materials costs due to inflation. [7] He concluded in his study that the rise in materials prices is due to inflation, which contributes to cost overrun.

\subsection{Factors responsible for increase in the cost of construction materials.}

Factors such as the change in government policies and legislations, scarcity of raw building materials, fluctuation in the cost of fuel and power supplies, inadequate infrastructural facilities, unfortunate corruption, fluctuation in the cost of plant and labor, and seasonal changes as being factors responsible for the escalating cost of building materials. Other factors responsible for the increase cost of building materials identified by researchers are these: fluctuation in the cost of transportation and distribution, political interference, local taxes and charges, fluctuation of cost of raw materials, cost of finance, inflation, and fluctuation in the exchange rate. Moreover, some macroeconomic indicators 
impacting the cost of building materials, which include the following: exchange rate of local currency to other currencies globally, inflation rate and interest rate charge on loans [8].

\subsubsection{Economic related factors of construction material cost.}

Exchange rate:- The building material costs are affected by exchange rates depends on the type and quantity of material being imported by a country at a specific time, the need to import the raw materials used in the production of building materials locally, and on whether or not local materials (such as copper, timber and steel are internationally traded commodities. According [4] Stated that the introduction of the foreign exchange market has had a detrimental impact of the prices of building materials

Interest rate:-The high interest rate of banks and the unpredictability in the foreign exchange market result in serious depletion of a nation's foreign exchange resources, harshly affecting the industry with import dependence of about $60 \%$ of its raw materials [9].

Across the nation, many constructions and profitable real estate projects and housing have either been put on hold or abandoned half way because of the scarcity of capital or because of the sky rocketing cost of borrowing [3]. Inadequate production of raw material: - According to [1] The reason for shortage of materials could be the ineffective supply of materials occasioned by general shortages in the industry, poor communication amidst sites and head office, poor purchasing planning and poor material coordination. Shortages of some construction materials may arise where the level of development activity is unusually high. If this had not been anticipated and integrated into the original cost estimate, the prices of these materials will increase. Ensuring a timely flow of materials is an imperative responsibility of material management, as unavailability of material will likely result in delays and extra expenses [6] Supply and demand of building materials: - Supply and demand of materials will determine the price of building materials. The demand for more housing and delay in supplying the building materials (or lack of materials), will add to the trends in the price of building materials, where the law of supply and demand can be related. Building materials cost increases are dependent on the market conditions under which they are manufactured. For example, the researchers noted that material cost will increases if only one or two companies are manufacturing building materials, as compared to those for which many manufacturers compete for the same market. A precondition for cost-effective construction is the availability of construction materials at the required time and location on site. Delay in the supply of materials on site is one causative factor of cost overruns in construction projects, particularly in developing countries [2].

\subsection{Research Design}

\section{RESEARCH METHODOLOGY}

The design used for this study is that of a survey which relied on a questionnaire surveys to generate data for the analysis. A five scale of measurements was used to determine the impact of cost inflation in building construction projects.

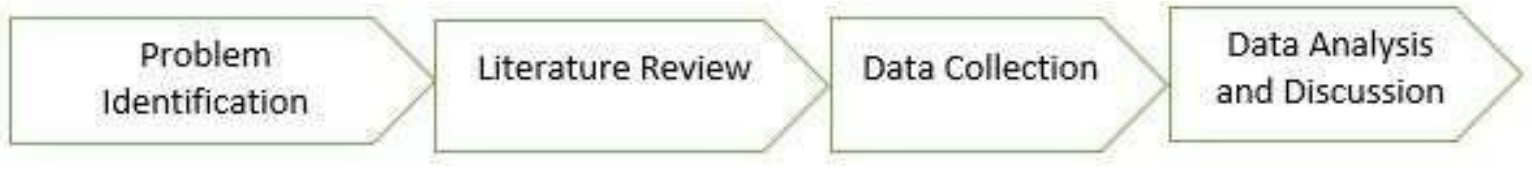

Figure 1: Flow Chart of for research design

The research data was obtained with the aid of a structured questionnaire survey (quantitative method), which was authenticated by conducting qualitative method shortly after the questionnaire survey. The quantitative method was used to collect data from construction stakeholders and contractors to identify factors causing impact of material inflation in building projects. Furthermore, exploratory type of study was employed in order to get a research questionnaire/surveys design to gain more perception into the research problem and to deliver solutions. [12]

\subsection{Data collection}

For successfully conduction we have used both primary and secondary data source. Primary data are data which the researchers used for the purpose of study at hand. Primary data is collected directly from the population by using selfadministered questionnaire and as a secondary data literature review from other sources is used.

\subsection{Population of the Study.}


The majority of the survey participants were construction professionals with all-embraced construction knowledge, skill and formal education. Site, contract, and project managers, site supervisors, designers, site engineers and quantity surveyors were the particularly nominated sample to denote the population for the purpose of this study. The buildings under construction were selected from the list of registered buildings in construction using multistage random sampling. From the list of registered buildings, every fifth buildings under construction were chosen using random sampling till the required sample was reached.From the total 48 distributed questionnaires 40 questionnaires were received and the study conducted.[14]

\subsection{Sampling Technique}

To confirm the data obtained from the questionnaires; contractors, site supervisors and government experts were interviewed. These participants were selected for interviews using the suitability sampling method. Participants interviewed had adequate experience in construction, with adequate years of experience and responsibilities in the construction sector.

\subsection{Instrument for Data Collection}

Data was collected using open-ended and close-ended questionnaires in relation with the research objectives. Qualitative interviews were used to confirm the findings obtained through the quantitative research. Moreover, observations were also used as a technique that helped to get information that is left during formal interview sessions with informants just to grasp information about the unstated things during the interview and informal conversation periods. [15]

\subsection{Techniques of Data Analysis}

Data were analyzed using descriptive analysis. All the statistical analyses and tests were done using application software "Microsoft excel". A Likert scale was used to measure the key indicators for cost inflation construction materials and to determine the range of each respondent's ranking of

0-4 (4 for EI (Extreme impact), 3 for HI (High Impact), 2 for AI (Average Impact), 1 for MI (Minor Impact) and 0 NI (No Impact)[16]

Finally, the Relative Important Index (RII) method was adopted for determining the rank for the "key factors Sustainable Construction Materials" by calculating the average of relative importance index of all factors in the group. $R I I=\left(\frac{\sum(W)}{A * N}\right)$

Where: $\mathrm{W}=$ the weight given to each factor by the respondents

$\mathrm{A}=$ Extreme impact $=4$

$\mathrm{N}=$ the total number of respondents.

\subsection{General Information}

\section{RESULTS AND DISCUSSION}

The objective of this study is to identify and determine the main impacts of inflation on construction material in wolaitasodo building construction projects. To accomplish this goals a questionnaire was developed and distributed to be filled by the concerned body in the construction sectors in WolaitaSodo.

Table1: Study Results from the respondents for the Key Factors for the impact of inflation construction material in wolaitasodo building construction projects 


\begin{tabular}{|c|c|c|c|c|c|c|c|c|}
\hline & $\begin{array}{l}\text { Always } \\
4\end{array}$ & $\begin{array}{l}\text { Often } \\
3\end{array}$ & $\begin{array}{l}\text { Usually } \\
2\end{array}$ & $\begin{array}{l}\text { Some } \\
\text { times } 1\end{array}$ & $\begin{array}{l}\text { Never } \\
0\end{array}$ & $\begin{array}{l}\text { Total } \\
10\end{array}$ & RII & Rank \\
\hline Key Factors & & & & & & & & \\
\hline Rising wage costs in labor market & 12 & 6 & 10 & 12 & 0 & 40 & 0.61 & 4 \\
\hline $\begin{array}{l}\text { Increasing raw material costs from domestic } \\
\text { and overseas supplies }\end{array}$ & 12 & 14 & 6 & 8 & 0 & 40 & 0.69 & 2 \\
\hline $\begin{array}{l}\text { Rising important prices due to falling } \\
\text { exchange rate }\end{array}$ & 15 & 13 & 7 & 5 & 0 & 40 & 0.74 & 1 \\
\hline $\begin{array}{l}\text { Higher indirect taxes imposed by the } \\
\text { government }\end{array}$ & 12 & 12 & 8 & 6 & 2 & 40 & 0.66 & 3 \\
\hline
\end{tabular}

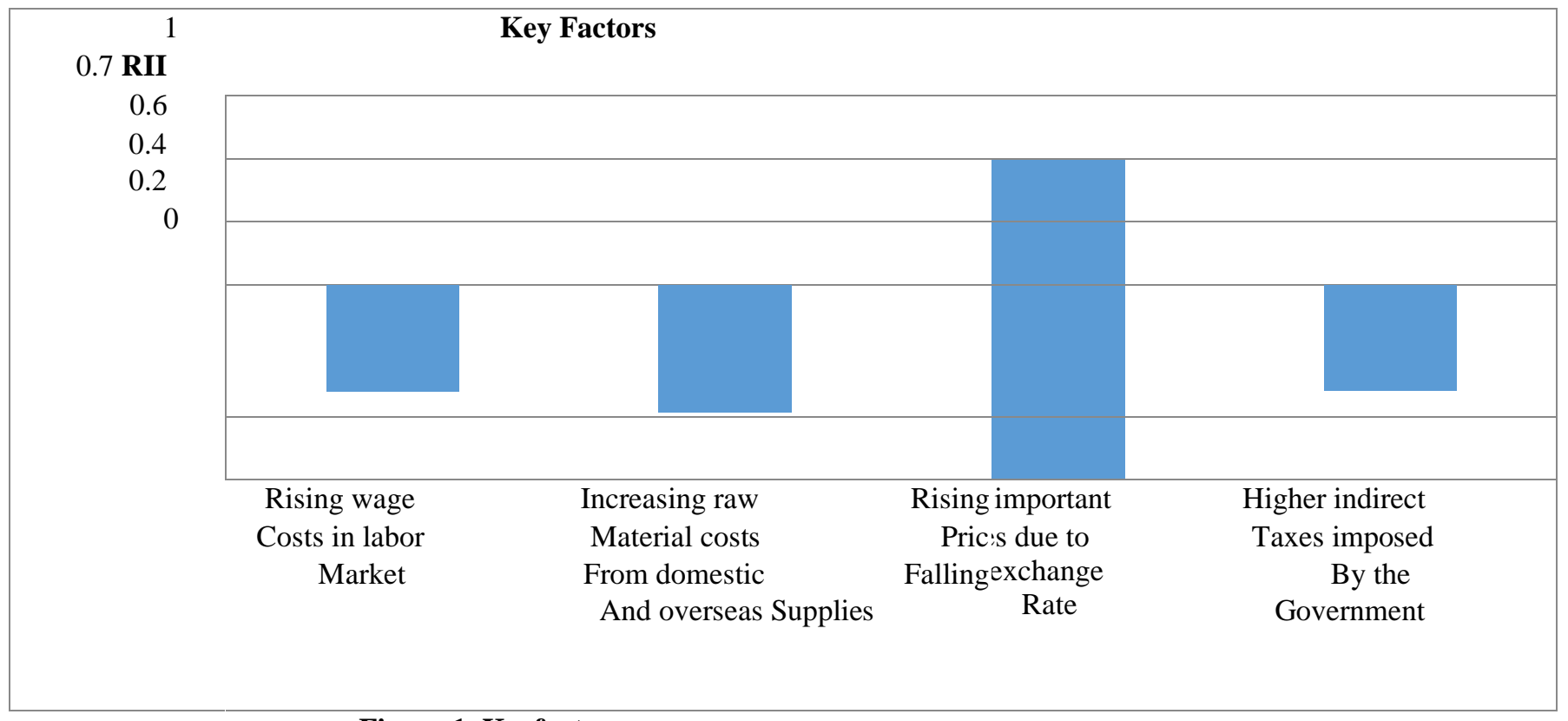

Figure 1. Keyfactors

From the average result shown on above table and figure, the major cause of material cost inflation is the rising important prices due to falling exchange rate with a RII of 0.74 which has high RII value. Rising wage costs in labor market causes minimumRII value, which is of 0.61 as we see from the above table

Table2: Study Results from the respondents for the impact of cost inflation on building construction material

\begin{tabular}{|l|l|l|l|l|l|l|l|}
\hline $\begin{array}{l}\text { Impact of cost inflation on building } \\
\text { construction material }\end{array}$ & EI 4 & $\begin{array}{l}\text { HI } \\
3\end{array}$ & $\begin{array}{l}\text { AI } \\
2\end{array}$ & $\begin{array}{l}\text { MI } \\
1\end{array}$ & $\begin{array}{l}\text { NI } \\
0\end{array}$ & Total & RII \\
\hline Delayed or Cancelled Projects & 10 & 10 & 7 & 8 & 5 & 40 & 0.58 \\
\hline Lack of Firm Price Quotes & 12 & 16 & 9 & 3 & 0 & 40 & 0.73 \\
\hline Reduced Numbers of Bidders & 16 & 5 & 16 & 1 & 2 & 40 & 0.70 \\
\hline Fluctuation in construction costs & 18 & 5 & 7 & 10 & 0 & 40 & 0.69 \\
\hline Cost over runs & 20 & 3 & 7 & 9 & 1 & 40 & 0.70 \\
\hline Dispute among parties & 21 & 6 & 9 & 1 & 3 & 40 & 0.76 \\
\hline
\end{tabular}




\begin{tabular}{|l|l|l|l|l|l|l|l|}
\hline $\begin{array}{l}\text { Cash flow (project financing) } \\
\text { problem of the projects }\end{array}$ & 16 & 13 & 8 & 3 & 0 & 40 & 0.76 \\
\hline Rate of employments is affected & 14 & 7 & 9 & 9 & 1 & 40 & 0.65 \\
\hline $\begin{array}{l}\text { Volume of construction output } \\
\text { affected }\end{array}$ & 18 & 7 & 6 & 6 & 3 & 40 & 0.69 \\
\hline Quality of workman ship affected & 16 & 16 & 7 & 1 & & 40 & 0.79 \\
\hline Risk of project abandonment & 18 & 15 & 3 & 4 & & 40 & 0.79 \\
\hline
\end{tabular}

from the average result shown on above table, the major impact of cost inflation on construction material price which have been occur on the projects are Quality of workman ship and and Risk of project abandonment with a RII of 0.79.Minimum impact cost inflation with a RII of 0.58 is Delayed or Cancelled Projectsas we see from the above table.

\section{CONCLUSTIONS}

The objectives of the research were to assess the impact of cost inflation on construction material price in wolaitasodo building projects. To achieve these objectives, the study used questionnaire survey as a research instrument. The information gathered from the survey was analyzed using the percentage method and relative importance index method.

Based on the results from the analysis the following conclusions have been derived and summarized in accordance with the objectives of the research.[17]The objective of this research was to assess the impact of cost inflation on construction material price. To achieve this, a questionnaire survey containing factors causing cost inflation: - Rising wage costs in labor market, increasing raw material costs from domestic and overseas supplies, rising important prices due to falling exchange rate higher indirect taxes imposed by the government. Impacts were Delayed or Cancelled Projects, Lack of Firm Price Quotes,Reduced Numbers of Bidder,Fluctuation in construction costs,Cost over runs, Dispute among parties, Cash flow (project financing) problem of the projects, Rate of employments is affected, Volume of construction output affected,Quality of workman ship affected,Risk of project abandonment.

\section{REFERENCES}

[1] Akanni, P.O, Oke,, A.E and Omotilewa, O.J., Implications of Rising Cost of Building Materials in Lagos State Nigeria.

[2] Ajanlekoko, E. (1990). The rise in cost of building material and the structural adjustment program.

[3] Dr.A. Paulmakesh, Yimam Mohammed Yimer April 2021, "Implementation of Project Management for Strategy Realisation” Journal of University shanghai for Science and Technology, Volume 23, Issue 10,Pg.No 887-892

[4] Akintola et.el, .. (2009). Macro-economic leading indicators of construction contract prices, Construction Management \& Economics. Taylor and Francis Journals. I

[5] Dr.A. Paulmakesh, Dec 2021, "Analysis of uncertainty in a construction project" YMER journal, Vol 20,Issue 12, pg.no 324-332.

[6] Akintola. (n.d.). Macro-economic leading indicators of construction contract prices, Construction Management \& Economics. Taylor and Francis Journals. .

[7] Yimam Mohammed, A. Paulmakesh, Bereket Admasu amd Saliha Shukri, Oct 2021, "Relationship between California Bearing Ratio and Other Geotechnical Properties of Sub grade Soils", ICEPAE 2021, Journal of Physics Conference Series, Vol 2040(1):012024, doi:10.1088/1742-596/2040/1/012029, pg.no 1-13.

[8] AstewayYigezu. (2008). Study on the Effects of Unpredictable Price Fluctuation on the Capacity of Construction Contractors.

[9] Atkeson, Andrew and Lee E. Ohanian. (2001). are phillips curves Useful for Forecasting Inflation.

[10] Dr.A. Paulmakesh, Gizachew Markos Makebo April 2021, "Management of contracts for Durable structures" Innovations, Number 64,Pg 1044-1054 
[11] Balsubaramanin, P. A. (October 2017,). Classification of Materials.

[12] Goyals, s. (2017). effecte of inflation on project cost in rajasthan.

[13] Hanna, A. T. (2005). Impact of extended overtime on construction labor productivity. . Journal of construction engineering and management, 734-739.

[14] Yimam Mohammed Yimer, A. Paul Makesh and SalihaShukri Muhammed, Oct 2021, "Prediction of undrained shear strength and correlation in between soil parameters", ICEPAE 2021, Journal of Physics Conference Series, Vol 2040(1):012029, doi:10.1088/1742-6596/2040/1/012024 pg.no 1-8.

[15] MAkulsawatudom, A. a. (2001). Factors affcting the productivity of the construction industry in Thailand:

[16]. Mohammed, G. (2013). Assessment of price escalation and adjestement problems on federal road construction projects.

[17] Muhammad, A. a. (2020). Impact of inflation rate on construction project budget. 